\title{
Susceptibility of Two Apple Cultivars to Infestation with European Red Mite Panonychus ulmi Koch (Acari: Tetranychidae)
}

\author{
M. F. Hassan*; A. A. El-Sherif ; ;. S. El- Badawy" and M. G. Draz ${ }^{* * *}$ \\ "Dept. of Zoology and Agric. Nematology, Fac. of Agric., Cairo Univ., Giza, Egypt. \\ ${ }^{* *}$ Pest Physiology Dept., Plant Protec. Res. Inst., Agric. Res. Cent., Giza, Egypt.
}

\begin{abstract}
Experiments were conducted to estimate the susceptibility of two apple cultivars (Anna and Golden dorset) to infestation with Panonychus ulmi Koch (Acari: Tetranychidae) and its population fluctuation during the two successive seasons, 2012 and 2013 at Menoufia governorate. The results showed that, Anna cultivar was the most highly susceptible recording average of 7.34 and 10.5 mite moving stages/leaf during the two successive seasons, respectively. The lower infestation was recorded with Golden dorset cultivar, being $1.6 \& 7.49$ mite moving stages/leaf during the two successive seasons, respectively. Susceptibility of apple cultivars to infestation with $P$. ulmi may be affected by plant leaf morphological structure and its chemical contents. The density of trichomes of Golden dorset cultivar was higher than that of Anna cultivar, the less density of trichomes the more mite infestation. Also, when the level of total phenolic compounds increased the infestation percentage decreased, while no effect of Tannins occurred. Mite populations reached its peak during May and April in the first and second seasons, respectively, and infestation was lower in the first season.
\end{abstract}

Key words: Susceptibility; Host plant resistance; Apple cultivars; Population dynamics; Panonychus ulmi.

\section{INTRODUCTION}

Apple Malus domestica Borkh. (Family: Rosaceae) is one of the most common crops in the world. It is usually infested with the European red spider mite; Panonychus ulmi Koch (Acari: Tetranychidae). So, evaluation the susceptibility of some apple cultivars to infestation with $P$. ulmi in order to select the most resistant ones is considered important to avoid using more pesticides. Chemical contents and morphological characteristics which normally vary from plant variety to another, may affect the population levels of herbivores. There were several studies on the host plant resistance to the infestation with Tetranychus urticae; Hanafy (2004) and Ibrahim et al., (2008).

The present work was conducted to determine the level of infestation of two apple cultivars with $P$. ulmi Koch, and its relationship with plant leaf morphological characteristics and certain chemical contents. The population dynamics of the mite throughout the two successive seasons; 2012 and 2013 was also studied.

\section{MATERIALS AND METHODS}

\section{Experimental procedures:}

Two Apple cultivars Anna and Golden Dorset were chosen for this study. An orchard of 7 years located in Ashmon, El-menoufia governorate was chosen to conduct the experiments during the two successive seasons; 2012 and 2013. The orchard was divided into 20 experimental units (15trees /unit). A row of trees separated the experimental units and the distances between trees was 3 meters.

To study the population dynamics of P. ulmi, weekly samples each of 20 leaves were randomly collected from each apple cultivar. Samples were collected from the first week of March till the second week of November during the two successive seasons 2012 and 2013. Leaf samples were transferred to the laboratory for examination and different stages of $P$. ulmi were counted.

The percentages of infested apple cultivars with $P$. ulmi were calculated according to El-Saiedy et al. (2011) formula.

\section{Morphological and Biochemical Studies: \\ 1- Morphological Studies}

Leaf samples of the tow apple cultivars were collected and imaged the upper and lower surface of apple leaves using the Analytical a Scanning Electron Microscopic Technique (SEM) (Joel jsm.6390LA) at the Central Laboratory of Water Station Fustat, Greater Cairo Water Company. Samples were washed in $0.1 \mathrm{M}$ phosphate buffer $(\mathrm{pH} 7)$ and post-fixed in $2 \%$ Osmium tetraoxide (OsO4) (pH 7). Samples were then taken through an alcohol dehydration series $(15 \%, 25 \%, 40 \%, 50 \%, 70 \%$, and $95 \%$ ETOH). SEM samples were critical point dried, sputter-coated to 20 $\mathrm{nm}$ with gold/paladium, and mounted on aluminum stubs for observation under a Phillips (SEM at 10-15 kV), Karnowsky (1965) and Fischer et al. (2012).

\section{2- Biochemical Studies}

Some specific chemical constituents of apple leaves were determined as follow:

\section{A. Extraction and determination of phenolic compounds: \\ a. Extraction:}

Ten plant leaves from each replicate (3 replicate for each treatment) were washed with water 
and placed in an oven to dry at $45^{\circ} \mathrm{C}$ for 4 days. Then they were grounded in an electric grinder into fine powder. Extraction was preformed as described by Kahkonen et al., (1999). Grounded plant seedlings $(5 \mathrm{gm})$ were extracted with $2 \times 10 \mathrm{ml}$ of $80 \%$ aqueous methanol using electric homogenizer for $5 \mathrm{~min}$. Samples were centrifuged (10min,3000r.p.m), and combined extracts were poured into pre-weighed small conical flasks. Methanol was removed under reduced pressure. The solid residue (crude extract) was weighed and dissolved in water to a $5 \mathrm{ml}$ volume.

\section{b. Determination}

The amount of total phenolic compounds in extracts was determined by Folin-Ciocateu method as modified by Singleton and Rossi (1965). The Folin- Ciocalteu reagent was prepared by adding 100 gm sodium tungstate, 25 gm phosphomolybdic acid, $100 \mathrm{ml} \mathrm{HCl}$, and $50 \mathrm{ml}$ orthophosphoic acid $(85 \%)$ to $700 \mathrm{ml}$ deionized water in conical flask. The flask was refluxed for 10 hours, cooled and then $150 \mathrm{gm}$ lithium sulphate was added. Few drops of liquid bromine were added to make the solution yellow in color and then the final volume was completed by deionized water to 1 liter. Two hundreds microliters of plant extracts were introduced into test tubes; $1 \mathrm{ml}$ of FolinCiocalteu reagent and $0.8 \mathrm{ml}$ of sodium carbonate (7.5\%) were added. The tubes were mixed and allowed to stand for 30 minutes. Absorption at 760 $\mathrm{nm}$ was measured against blank containing everything except the sample. The Folin-Ciocalteu reagent is sensitive to reducing compounds including polyphenols, thereby producing a blue color upon reaction. Gallic acid standard was used, and the total phenolic content was expressed as $\mathrm{mg} / \mathrm{g}$ gallic acid equivalents (GAE).

\section{B. Extraction and determination of tannins:}

Tannins were extracted, from samples, using 70 per cent aqueous acetone. The contents were centrifuged $\left(3,000 \mathrm{~g}\right.$ at $4^{\circ} \mathrm{C}$ for $\left.10 \mathrm{~min}\right)$ and the supernatant was taken for determination of tannins. Total phenols and simple phenols were estimated using folin-ciocalteu reagent using tannic acid as a standard (Makkar et al., 1993) and net tannins were calculated by difference between total phenols and simple phenols.

\section{RESULTS AND DISCUSSION}

\section{Susceptibility of two apple cultivars to $P$. ulmi infestation:}

The tested apple cultivars could be arranged in descending order according to their susceptibility to infestation with $P$. ulmi during the two seasons, 2012 and 2013 as follows: Anna cultivar was more significant susceptible to infestation than Golden dorset cultivar. It recorded $2.53(71 \%)$ motile mite stages / leaf during season (2012) and 3.9 (63\%) motile mite stages / leaf during season (2013), The lowest infestation was observed with Golden dorset cultivar, being 0.99 (28.97) and $2.3(37.10 \%)$ for the latter cultivar during the two successive seasons, respectively (Table 1 ).

\section{Morphological and Biochemical Studies: \\ 1- Morphological Studies}

Susceptibility of apple cultivars to infestation with $P$. ulmi may be affected by plant leaf morphological structure. Therefore the differences between the two apple cultivars, Anna and Golden dorset, in their leaf morphological structure were studied. The density of leaf trichomes on lower surfaces of Golden dorset cultivar was higher than that of Anna cultivar. (Figs. $1 \& 2$ ); while the density of leaf trichoms on upper surfaces showed almost the same in the two apple cultivars.

Host plant resistance depends on many factors, including morphological characters; i.e. plant surface (Tingey and Laubengayer, 1982; Juniper and Jeffree, 1983). Morphological characteristics within a plant species may play an important role in host plant preference because it may affect insect feeding (Hoffman and McEvoy, 1985). Warabieda et al. (1997) investigated the morphological and anatomical characters of apple leaves associated with cultivar susceptibility to T. urticae infestation. The lower (abaxial) epidermis of the leaves seemed to suggest that the layout and thickness of cuticle, rather than the epidermal thickness itself could be a factor determining the susceptibility of apple cultivars to

Table (1): Susceptibility of two apple cultivars to $P$. ulmi infestation during 2012\&2013 seasons.

\begin{tabular}{lcccc}
\hline \multirow{2}{*}{$\begin{array}{l}\text { Apple } \\
\text { cultivars }\end{array}$} & \multicolumn{4}{c}{ Mean number of $P$. ulmi motile stages / leaf \pm} \\
\cline { 2 - 5 } & \multicolumn{2}{c}{ 2012 season } & 2013 season \\
\cline { 2 - 5 } & Mean & Infestation & Mean & Infestation \\
$\%$ & No. & $\%$ \\
\hline Go. & 28.98 & $2.30 \pm 0.86$ & 37.10 \\
\hline Anna & $2.53 \pm 0.79$ & 71.02 & $3.90 \pm 1.36$ & 62.90 \\
\hline LSD 0.05 & 10.446 & \multicolumn{4}{c}{21.1} \\
\hline
\end{tabular}

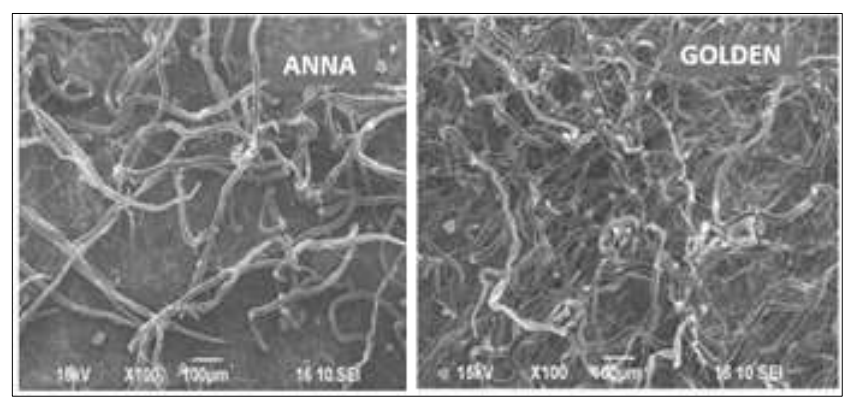

Fig. (1). Scanning electron micrographs of lower surfaces leaf trachoms for two apple cultivars. 


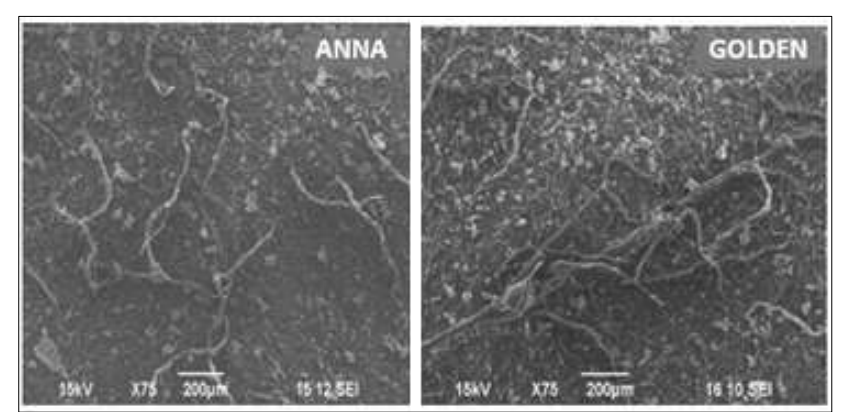

Fig. (2). Scanning electron micrographs of upper surfaces leaf trachoms for two apple cultivars.

Table (2): Relationship between phytochemical components of two apple cultivars leaves and high infestation peak of $P$. ulmi

\begin{tabular}{cccc}
\hline \multirow{2}{*}{$\begin{array}{c}\text { Apple } \\
\text { cultivars }\end{array}$} & $\begin{array}{c}\text { Mean } \\
\text { number of } P .\end{array}$ & \multicolumn{2}{c}{ Phytochemical Components } \\
\cline { 3 - 4 } & $\begin{array}{c}\text { Total phenol } \text { motile } \\
\text { stages }\end{array}$ & $\begin{array}{c}\text { Total GA/gm fresh } \\
\text { weight }\end{array}$ & $\begin{array}{c}\text { Total tannins } \\
\text { ug GA/gm } \\
\text { fresh weight }\end{array}$ \\
\hline Golden & $2.30^{\mathrm{a}}$ & $3076.67^{\mathrm{b}}$ & $583.67^{\mathrm{a}}$ \\
Anna & $3.90^{\mathrm{b}}$ & $3912.00^{\mathrm{a}}$ & $575.33^{\mathrm{a}}$ \\
\hline Correlation Coefficient $(r)$ & 0.9593 & 0.0221 \\
\hline
\end{tabular}

Table (3): Population dynamics of Panonychus ulmi Koch stages / leaf on two apple cultivars during 2012 season

\begin{tabular}{|c|c|c|c|c|}
\hline \multirow{2}{*}{$\begin{array}{c}\text { Sampling } \\
\text { dates }\end{array}$} & \multicolumn{2}{|c|}{ Motile stages } & \multicolumn{2}{|c|}{ Eggs } \\
\hline & Golden & Anna & Golden & Anna \\
\hline Mar & 0.30 & 0.48 & 2.1 & 4.18 \\
\hline Apr & 1.66 & 4.06 & 4.33 & 7.00 \\
\hline May & 1.10 & 7.34 & 2.13 & 47.23 \\
\hline Jun & 1.26 & 1.30 & 0.74 & 1.89 \\
\hline Jul & 0.52 & 0.67 & 1.67 & 2.08 \\
\hline Aug & 0.30 & 0.54 & 0.88 & 1.94 \\
\hline Sep & 0.93 & 1.48 & 0.55 & 2.68 \\
\hline Oct & 1.35 & 2.98 & 0.65 & 5.57 \\
\hline Nov & 1.53 & 3.08 & 2.65 & 4.58 \\
\hline Mean & $0.99^{\mathrm{a}}$ & $2.53^{\mathrm{b}}$ & $1.76^{\mathrm{a}}$ & $9.47^{\mathrm{b}}$ \\
\hline LSD at 0.05 & \multicolumn{2}{|c|}{0.89} & \multicolumn{2}{|c|}{7.49} \\
\hline
\end{tabular}

Table (4): Population dynamics of Panonychus ulmi Koch stages / leaf on two apple cultivars during 2013 season

\begin{tabular}{ccccc}
\hline \multirow{2}{*}{$\begin{array}{c}\text { Sampling } \\
\text { dates }\end{array}$} & \multicolumn{2}{c}{ Motile stages } & \multicolumn{2}{c}{ Eggs } \\
\cline { 2 - 5 } & Golden & Anna & Golden & Anna \\
\hline Mar & 0.22 & 1.50 & 2.22 & 3.02 \\
\hline Apr & 5.00 & 10.50 & 8.3 & 54.00 \\
\hline May & 7.49 & 10.39 & 9.61 & 58.84 \\
\hline Jun & 0.83 & 1.68 & 6.28 & 14.13 \\
\hline Jul & 0.80 & 1.03 & 1.3 & 2.25 \\
\hline Aug & 0.53 & 0.93 & 0.43 & 1.25 \\
\hline Sep & 1.18 & 1.83 & 1.43 & 2.58 \\
\hline Oct & 2.20 & 3.83 & 2.38 & 4.10 \\
\hline Nov & 2.50 & 3.48 & 4.03 & 7.75 \\
\hline Mean & $2.30^{\mathrm{a}}$ & $3.90^{\mathrm{b}}$ & $3.99^{\mathrm{a}}$ & $16.43^{\mathrm{b}}$ \\
\hline LSD at 0.05 & \multicolumn{2}{c}{1.13} & \multicolumn{3}{c}{9.52} \\
\hline \multicolumn{5}{c}{}
\end{tabular}

T. urticae. Host plant resistance is based on certain morphological, and/or chemical plant defensive factors (Pedigo, 2006).

\section{2- Biochemical Studies}

One of the most important factors which may explain the susceptibility or tolerance of apple cultivars to $P$. ulmi infestation is the phytochemical components of their leaves. Therefore, this study was carried out during the peak of season 2013 to determine the relationship between $P$. ulmi infestation at peak season level /leaf and the phytochemical components of the studied apple cultivars. The high mean number of $P$. ulmi motile stages occurred on the leaves of Anna cultivar, which associated with lower levels of total phenolic compounds (Table 2) and this indicated a negative correlation with the population densities; while with tannins indicated no correlation with the population densities as a resultant throughout the growing season.

The Golden dorset cultivar recorded low infestation rate of $P$. ulmi motile stages, and this was associated with higher levels of total phenolic compounds therefore there is a negative correlation occurred between them (Table 2). Generally the obtained data indicated that there was a negative relationship occurred between mite infestation levels and total phenolic compounds in Apple cultivar leaves. In Anna cultivar the average of total phenolic was 3076 (ug GA/gm fresh weight), while in Golden dorset cultivar the average was 3912 (ug GA/gm fresh weight) (Table 2).

These results are in agreement with those recorded by; Pree, (1977) who stated that, the Phenolic compounds, i.e., Phloridzin which was mainly found in high concentration in the foliage of Malus taxa, miaht play an important role in insect resistance. Phenolics are important defense chemical compounds. Apple leaves from different genotypes (Malus spp.) contain various levels of phenolic compounds such as chlorogenic acid, gallic acid, quercitrin, phloridzin, and phloretin (Garcia et al., 1995).

Hanley et al. (2007) found that the biochemical mechanisms of defense against the herbivores are wide-ranging, highly dynamic, and are mediated both by direct and indirect defenses. The defensive compounds are either produced constitutively or in response to plant damage, and affect feeding, growth, and survival of herbivores. Direct defenses are mediated by plant characteristics that affect the herbivore's biology such as mechanical protection on the surface of the plants (e.g., hairs, trichomes, thorns, spines, and thicker leaves) or production of toxic chemicals such as terpenoids, alkaloids, anthocyanins, phenols, and quinones) that either kill 


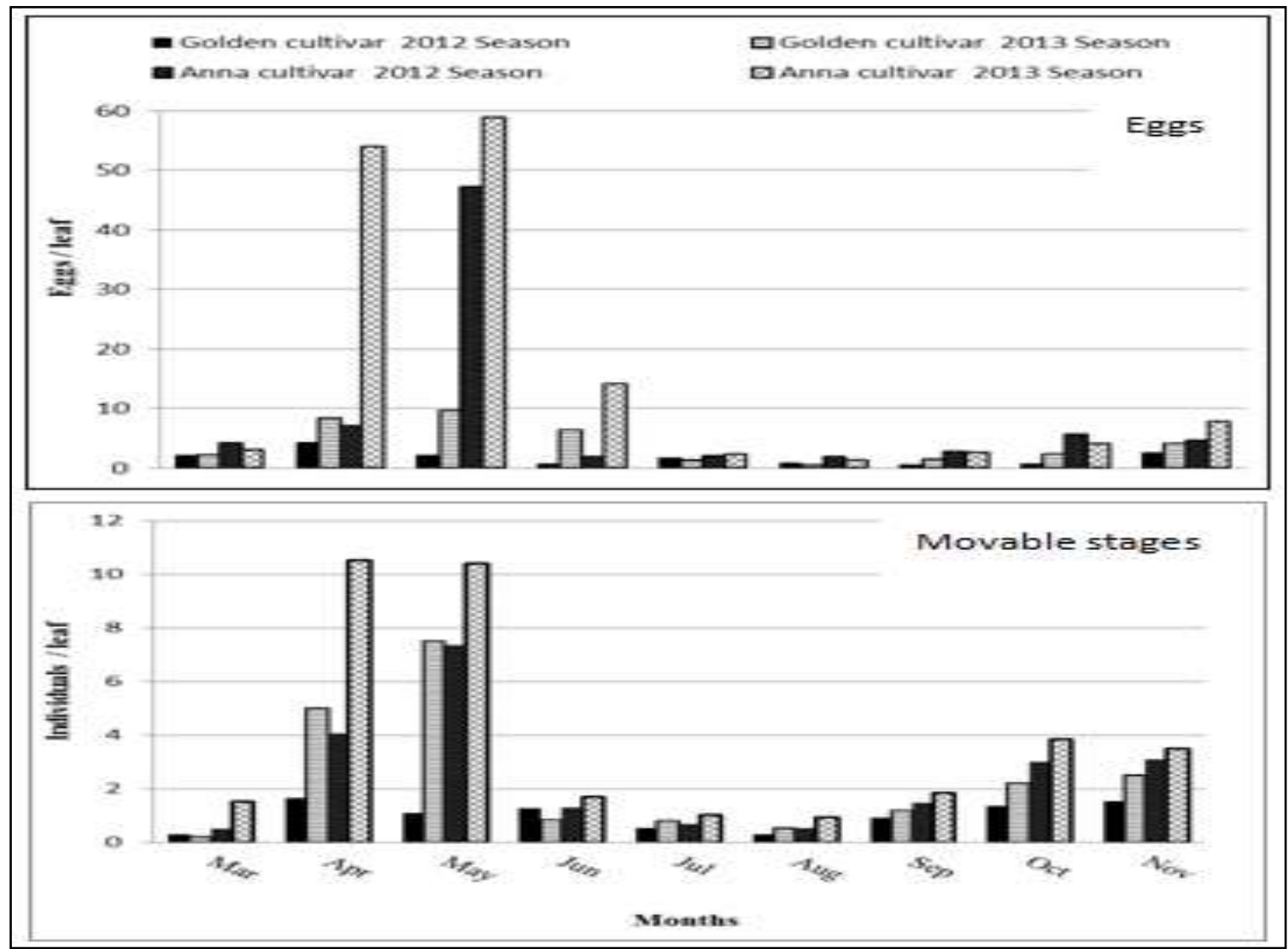

Fig. (3). Mean number of $P$. ulmi motile stages and eggs on two apple cultivars during 2012 and 2013 seasons.

or retard the development of the herbivores.

\section{Population dynamics of Panonychus ulmi on two apple cultivars}

Population dynamics of European Red Mite, Panonychus ulmi Koch were recorded during season 2012 from the second week of March till the second week of November and during season 2013 from the second week of March till the second week of November.

Data in tables (3\&4) and illustrated in Fig. (3) revealed that the infestation of apple cultivars Anna and Golden dorset with P. ulmi started on March then gradually increased to reach its peak in April for Golden dorset cultivar, and in May for Anna cultivar during 2012 season; while in 2013 season, infestation started in the end of March, then gradually increased to reach its peaks in May for both Anna and Golden dorset cultivars.

Population density of $P$. ulmi motile stages and eggs / leaf of Anna and Golden dorset cultivars averaged $(0.48 \& 4.18$; and $0.30 \& 2.10),(1.50 \&$ 3.02 and $0.22 \& 2.22$ ) at the beginning of infestation during 2012 and 2013 seasons, respectively; while in the high peak of infestation it averaged $(7.34 \& 47.23$ and $1.66 \& 4.33),(10.50 \& 58.84$ and $7.49 \& 9.61$ individuals / leaf) during 2012 and 2013 seasons, respectively.
The population of $P$. ulmi started to decrease from Jun in Anna cultivar, and in the end of May in Golden dorset cultivar during 2012 season, while during 2013 season it started to decrease from June in Anna and Golden dorset cultivars.

The mean numbers of $P$. ulmi motile stages and eggs at the two apple cultivars; Anna and Golden dorset averaged $2.44 \& 8.57$ and $0.99 \& 1.74$ during 2012 season, respectively, while it averaged $3.90 \&$ 16.43; and $2.30 \& 3.99$ individual / leaf during 2013 season, respectively. Thus, it is clear that Anna cultivar was more susceptible to the European red spider mite infestation.

Finally, it could be concluded that the numbers of eggs and motile stages of $P$. ulmi reached its peak during May in seasons 2012 and 2013. Then it slightly decreased, recorded the lowest numbers at Aug.

Statistical analysis in tables (3\&4) showed that there are significant differences between the numbers of $P$. ulmi stages during all two seasons 2012 and 2013. The obtained results revealed that there was significant differences between Anna and Golden dorset cultivars.

These results were in agreement with those recorded by Kitashima and Gotoh (2003) who stated that, the $P$. osmanthi population was bimodal with 
one peak in spring (May-June) and another in winter (November-January). Also, Baiming et al. (2007) stated that, two population peaks appeared in a year in the orchards infested with $P$. ulmi, the first in the last 20 days of June and the next in the beginning of August. The population fluctuation of $P$. ulmi differed during the two studied seasons, but the peak was recorded during May or June in both seasons according to the grapevine cultivars, Mannaa et al. (2012).

\section{REFERENCES}

Baiming, H.; Dayong, J. and Longshi, L. 2007. Threshold temperature for development and population dynamics of Panonychus ulmi Koch in fields. Plant Protection, (4): 83-86.

El-Saiedy, E. M. A.; Afifi, A. M.;Ali, F S. and Ahmed, M. M. 2011. Susceptibility of four Watermelon cultivars to infestation with Tetranychus urticae Koch. Acarines, 5(1): 23-28.

Fischer, E. R.; Hansen, B. T.; Nair, V.; Hoyt, F. H., and Dorward, D. W. 2012. Scanning Electron Microscopy. Curr Protoc Microbiol, 76p.

Garcia, M. E.; Rom, C. R.; Murphy, J. B. and Felton G. W. 1995. Phenolic variation in Malus sp. Hort Science, 30: 830.

Gotoh, T.; Ishikawa, Y. and Kitashima, Y. 2003. Lifehistory traits of the six Panonychus species from Japan (Acari: Tetranychidae). Exp. \& Appl. Acarol., 29(3-4):241-52.

Hoffman, G. D. and McEvoy, P. B. 1985. Mechanical limitations of feeding by meadow spittlebugs Philaenus spumarius (Homoptera: Cercopidae) on wild and cultivate host plants. Ecol. Entomol., 10: 415-426.

Hanafy, A. R. I. 2004. Studies on the most important cucumber pests in the open field and suitable control programs. Ph.D. Thesis. Fac. of Agric., Moshtohor, Zagazig Univ., 279pp.

Hanley, N.; Wright, E. R. and Alvarez-Farizo, B. 2007. Estimating the economic value of improvements in river ecology using choice experiments: an application to the water framework directive. In Environmental Value Transfer: Issues and Methods, eds. S. Navrud and R. Ready, 111-130.

Ibrahim, M. M. S.; El-Esnawy, B. A. and El-Adawy,
A. M. 2008. Imbrications of certain cucurbit crops characteristics with the two-spotted spider mite infestation. J. Acarines, 2: 61-65.

Juniper, B. E. and Jeffree, C. E. 1983. Plant surfaces. Edward Arnold, London. P. 93.

Karnowsky, M. J. 1965. A formaldehydeglutaraldehyde fixative of high osmolarity for use in electron microscopy. Journal of Cell Biology, 27: 137A.

Kahkonen, M. P.; Hopia, A. I.; Vuorela, H. J.; Rauha, J. P.; Pihlaja, K.; Kujala, T. S. and Heinonen, M. 1999. Antioxidant activity of plant extracts containing phenolic compounds. Journal of Agricultural and Food Chemistry, 47: 3954-3962.

Miles, P. W. 1972. The saliva of Hemiptera. Advances in Insect Physiology, 9: 183-255

Makkar, H.P.S.; Blummel, M.; Borowy, N.K. and Becker, K. 1993. Gravimetric determination of annins and their correlations with chemical and protein precipitation methods. Journal of Science and Food Agriculture, 61:161-165.

Mannaa, S. H.; Al-Zyoud, F. A. and Saleh, A. M. M. 2012. Effect of certain abiotic and biotic factors on population dynamics of Retithrips syriacus Mayet (Thripidae: Thysanoptera) and Panonychus ulmi Koch (Tetranychidae: Prostigmata) infesting grapevine. Bulletin of Faculty of Agriculture, Cairo University, 63(2):201-211.

Pedigo, L. P. 2006. Entomology and Pest Management. $4^{\text {th }}$ edn. Dorling Kindersley (India) Pvt. Ltd. New Delhi: 175-210.

Pree, D. J. 1977. Resistance to development of larvae of the apple maggot in crab apples. J. Econ. Entomol., 70: 611-614.

Singleton, V. L. and Rossi, J. A. 1965. Colorimetry of total phenolics with phosphomolybdic phosphotungstic acid reagents. Am. J. Enol. Viticult., 16: 144-158.

Tingey, W. M. and Laubengayer, J. E. 1982. Defense against the green peach aphid Myzus persicae and potato leafhopper Empoasca fabae by glandular trichomes of Solanum berthaultii. J. Econ. Entomol., 74: 721-725.

Warabieda, W.; Olszak, R. W. and Dyki, B. 1997lihbvi. Morphological and anatomical characters of apple leaves associated with cultivar susceptibility to spider mite infestation. Acta agrobotanica, 50(1-2):53-64. 